\title{
Resilience of imperilled headwater stream fish to an unpredictable high-magnitude flood
}

\begin{tabular}{|c|c|}
\hline \multicolumn{2}{|c|}{$\begin{array}{l}\text { Authors: } \\
\text { Bruce R. Ellend } \\
\text { Olaf L.F. Weyl }\end{array}$} \\
\hline \multicolumn{2}{|c|}{$\begin{array}{l}\text { Affiliations: } \\
{ }^{1} \text { South African Institute } \\
\text { for Aquatic Biodiversity, } \\
\text { Grahamstown, South Africa }\end{array}$} \\
\hline \multicolumn{2}{|c|}{$\begin{array}{l}{ }^{2} \text { Department of Ichthyology } \\
\text { and Fisheries Science, } \\
\text { Rhodes University, } \\
\text { South Africa }\end{array}$} \\
\hline \multicolumn{2}{|c|}{$\begin{array}{l}{ }^{3} \text { Centre for Invasion Biology, } \\
\text { South African Institute } \\
\text { for Aquatic Biodiversity, } \\
\text { Grahamstown, South Africa }\end{array}$} \\
\hline \multicolumn{2}{|c|}{$\begin{array}{l}\text { Correspondence to: } \\
\text { Bruce Ellender }\end{array}$} \\
\hline \multicolumn{2}{|c|}{$\begin{array}{l}\text { Email: } \\
\text { bru.ellender@gmail.com }\end{array}$} \\
\hline \multicolumn{2}{|c|}{$\begin{array}{l}\text { Postal address: } \\
\text { Private Bag 1015, } \\
\text { Grahamstown 6140, } \\
\text { South Africa }\end{array}$} \\
\hline \multicolumn{2}{|c|}{$\begin{array}{l}\text { Dates: } \\
\text { Received: } 04 \text { Nov. } 2014 \\
\text { Accepted: } 27 \text { Jan. } 2015 \\
\text { Published: } 22 \text { May } 2015\end{array}$} \\
\hline \multicolumn{2}{|c|}{$\begin{array}{l}\text { How to cite this article: } \\
\text { Ellender, B.R. \& Weyl, } \\
\text { O.L.F., 2015, 'Resilience of } \\
\text { imperilled headwater stream } \\
\text { fish to an unpredictable } \\
\text { high-magnitude flood', } \\
\text { Koedoe } 57(1), \text { Art. \#1258, } \\
8 \text { pages. http://dx.doi. } \\
\text { org/10.4102/koedoe. } \\
\text { v57i1.1258 }\end{array}$} \\
\hline \multicolumn{2}{|c|}{$\begin{array}{l}\text { Copyright: } \\
\text { (C) 2015. The Authors. } \\
\text { Licensee: AOSIS } \\
\text { OpenJournals. This work is } \\
\text { licensed under the Creative } \\
\text { Commons Attribution } \\
\text { License. }\end{array}$} \\
\hline \multicolumn{2}{|l|}{ Read online: } \\
\hline 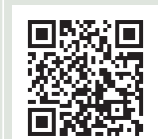 & $\begin{array}{l}\text { Scan this QR } \\
\text { code with your } \\
\text { smart phone or } \\
\text { mobile device } \\
\text { to read online. }\end{array}$ \\
\hline
\end{tabular}

Headwater stream fish communities are increasingly becoming isolated in headwater refugia that are often cut off from other metapopulations within a river network as a result of nonnative fish invasions, pollution, water abstraction and habitat degradation downstream. This range restriction and isolation therefore makes them vulnerable to extinction. Understanding threats to isolated fish populations is consequently important for their conservation. Following a base-flow survey, a high-magnitude flood (peak flow of $1245 \mathrm{~m}^{-3} \mathrm{~s}^{-1}$ ) provided an opportunity to investigate the response of endangered Eastern Cape redfin Pseudobarbus afer populations to a natural disturbance in the Waterkloof and Fernkloof streams, two relatively pristine headwater tributaries of the Swartkops River system within the Groendal Wilderness Area, Eastern Cape Province, South Africa. Pseudobarbus afer had limited distributions, occupying $3 \mathrm{~km}$ in both the Fernkloof and Waterkloof streams. Fish population assessments before and after the flood event indicated that there were no longitudinal trends in P. afer abundance before or after the flood, but overall abundance post-flooding in the Fernkloof stream was higher. There were no noticeable changes in P. afer size structure pre- and post-flood. Pseudobarbus afer showed resilience to a major flooding event most likely related to evolution in river systems characterised by environmental stochasticity.

Conservation implications: This research provides insight into the population level responses of native headwater stream fishes to unpredictable natural disturbance. Of particular relevance is information on their ability to withstand natural disturbances, which provides novel information essential for their conservation and management especially as these fishes are already impacted by multiple anthropogenic stressors.

\section{Introduction}

Headwater stream fishes in South Africa are increasingly being isolated in small fragmented headwater refuges as a result of competition with and predation by non-native fishes, downstream water abstraction, pollution and habitat degradation (Marr et al. 2010; Tweddle et al. 2009; Weyl et al. 2014). Protected areas play an important role in conserving headwater fishes by preserving habitats and preventing non-native fish introductions (Russell 2011). It is increasingly recognised, however, that the persistence of fishes in these environments may be dependent on dispersal between complementary habitats for reproduction, feeding, rearing and disturbance avoidance (Franssen et al. 2006; Labbe \& Fausch 2000; Schlosser \& Angermeier 1995). Isolation may therefore compromise their long-term persistence (Fausch et al. 2009). Understanding the vulnerability of isolated refuge populations to natural catastrophic events such as flooding is therefore important for conservation planning.

Headwater streams are considered particularly susceptible to floods because they have small catchments and are easily influenced by relatively minor changes in local conditions (Meyer et al. 2007). Unpredictable, infrequent and catastrophic floods can result in slope failures, bank erosion, substrate scouring, and loss of habitat and biota (Resh et al. 1988). In fish populations, floods can result in downstream displacements (Cambray 1994), reduced abundance (Magalhaes, Schlosser \& Collares-Pereira 2003; Matthews 1986; Nislow et al. 2002; Pires et al. 2008), recruitment failure (Letcher \& Terrick 1998) and alteration in community composition (Matthews 1986; Nislow et al. 2002).

Despite the documented impacts of floods on stream fish communities (Letcher \& Terrick 1998; Matthews 1986; Nislow et al. 2002; Pires et al. 2008; Resh et al. 1988), fishes also display long-term resilience and have been shown to return to equilibrium fairly rapidly following catastrophic flood events (Dolloff, Flebbe \& Owen 1994; Matthews 1986). Under natural conditions, fishes are able to recolonise disturbed stream reaches from metapopulations in undisturbed refuge habitats (Dolloff et al. 1994; Matthews 1986; Medeiros \& Maltchik 2001). 
Isolation is a concern for freshwater fish conservation in South Africa, where many headwater stream fishes are endemic to individual river systems and populations are increasingly fragmented by man-made (dams, weirs) or biological (invasive fish predation) barriers (Ellender, Weyl \& Swartz 2011; Tweddle et al. 2009). One such species is the Mandela lineage of the endangered Eastern Cape redfin minnow, Pseudobarbus afer (Peters, 1864) (Swartz \& Impson 2007). Its natural distribution is limited to only three river systems (Sundays, Swartkops and Baakens) in the Eastern Cape Province of South Africa (Swartz, Skelton \& Bloomer 2007). Populations are heavily impacted by non-native fish predation (Ellender et al. 2011) and only persist in isolated headwater refugia (Ellender 2013). Fortunately, a considerable portion of these headwater refugia are located in two protected areas, the Addo Elephant National Park (Sundays River system) and the Groendal Wilderness Area (Swartkops River system). Whilst these protected areas provide protection from non-native fishes and habitat destruction, the impact of natural catastrophic floods on these isolated populations are unknown.

This article provides insight into the population level responses of $P$. afer to an unpredictable high-magnitude flood event by comparing the distributions, relative abundance and population structure of P. afer in two headwater streams before and after an unpredictable high-magnitude flood. It was hypothesised that the flood would (1) result in displacement and mortality of headwater fishes, resulting in changes in abundance and distribution in headwater streams and (2) that juvenile life history stages of $P$. afer would be more vulnerable to flood disturbance.

\section{Research method and design \\ Study site}

The study was undertaken within the Groendal Wilderness Area on two second-order, episodic headwater tributaries (Fernkloof stream, Waterkloof stream) of the Kwa-Zunga River, a major tributary of the Swartkops River system, Eastern Cape, South Africa (Figure 1). As a result of their entire catchments being situated within the Groendal Wilderness Area (a protected area proclaimed for the protection of indigenous forest and water resources), the Fernkloof and Waterkloof streams are relatively pristine with undammed catchments and intact riparian zones characterised by closed canopy (Fernkloof: $46 \% \pm 23 \%$ canopy cover; Waterkloof: $33 \% \pm 24 \%$ canopy cover) tropical coastal forest (Acocks 1975) and mesic grassy fynbos (Campbell 1985). The character of the two streams is typical for episodic headwater streams in the Eastern Cape. Both streams have steep, high profile banks within narrow valleys. In-stream habitat was characterised by isolated pools (Fernkloof [mean \pm s.d.] length: $10.8 \mathrm{~m} \pm 3.2 \mathrm{~m}$; width: $3.6 \mathrm{~m} \pm 0.9 \mathrm{~m}$; depth: $0.7 \mathrm{~m} \pm 0.4 \mathrm{~m}$; Waterkloof [mean \pm s.d.] length: $11.9 \mathrm{~m} \pm 3.7 \mathrm{~m}$; width: $5.5 \mathrm{~m} \pm 4.8 \mathrm{~m}$; depth: $0.7 \mathrm{~m} \pm$ $0.6 \mathrm{~m}$ ) connected by subsurface flows, with bedrock, large unconsolidated boulder, cobble and pebble substrates.
Surface flow only connects pools for a few days after heavy sustained rainfall.

\section{Field surveys}

Ten sites on each stream were sampled before (May 2010) and two months after (August 2012) a major flooding event (June 2012) by electrofishing using a Samus 725G backpack electrofisher, attached to a $12 \mathrm{~V}$ battery with settings standardised at the duration of $0.3 \mathrm{~ms}$ and a frequency of $80 \mathrm{~Hz}$. Because flood scouring and filling changed the position of pools within the two streams in the post-flood survey, the nearest pool to the pre-flood sample site was electrofished. Single-pass electrofishing was conducted from the downstream side (tail) of the pool in an upstream direction, covering the entire length of each pool. Upon completion of the pass, fish were identified to species level, measured, counted and released. Electrofishing data were used as an index of relative abundance and catch per unit effort (CPUE) was expressed as fish $\mathrm{m}^{-3}$ using volume estimates from the habitat data collected for each sampled pool. Block nets were not used as pools were primarily isolated on the surface because of the episodic nature of the sampled streams.

At each sampling site, temperature, conductivity and $\mathrm{pH}$ were measured using a Hanna HI98129 Combo pH and electrical conductivity meter (HANNA Instruments Inc., Woonsocket, USA). Turbidity (NTU) was measured using a Hanna HI 98703 turbidimeter (HANNA Instruments Inc., Woonsocket, USA). To estimate pool volume and habitat diversity, the length $( \pm 0.1 \mathrm{~m})$ of the pool was measured, followed by equally spaced width measurements $( \pm 0.1 \mathrm{~m})$. On each width transect, three depths $( \pm 0.1 \mathrm{~m})$ were measured; the outer two were $0.2 \mathrm{~m}$ each from the left-hand and righthand stream bank and the third measurement taken midstream. At each depth measurement, the habitat type was recorded. Canopy cover was estimated as a percentage of total cover and bankside vegetation type was recorded.

\section{Data analysis \\ Rainfall and flow}

Long-term hydrological and meteorological data were obtained from the Department of Water Affairs hydrology section (DWAF 2012); the locations of the rainfall and gauging stations are presented in Figure 1. These data were used to illustrate rainfall, flow variability and the magnitude of the flood in the headwaters of the Swartkops River system. Because of an absence of long-term flow data for the Fernkloof and Waterkloof streams, flow data were obtained from a representative Swartkops River system headwater tributary, the gauging weir at Wincanton on the Elands River (M1H004) for the period 06 April 1965 - 05 January 2012. Rainfall data were obtained from station M1E001 at Groendal Dam (period: 16 February 1950 - 11 January 2006) and supplemented with data from the nearby station M1E002 at Uitenhage (period: 30 November 2006 - 05 January 2012). 


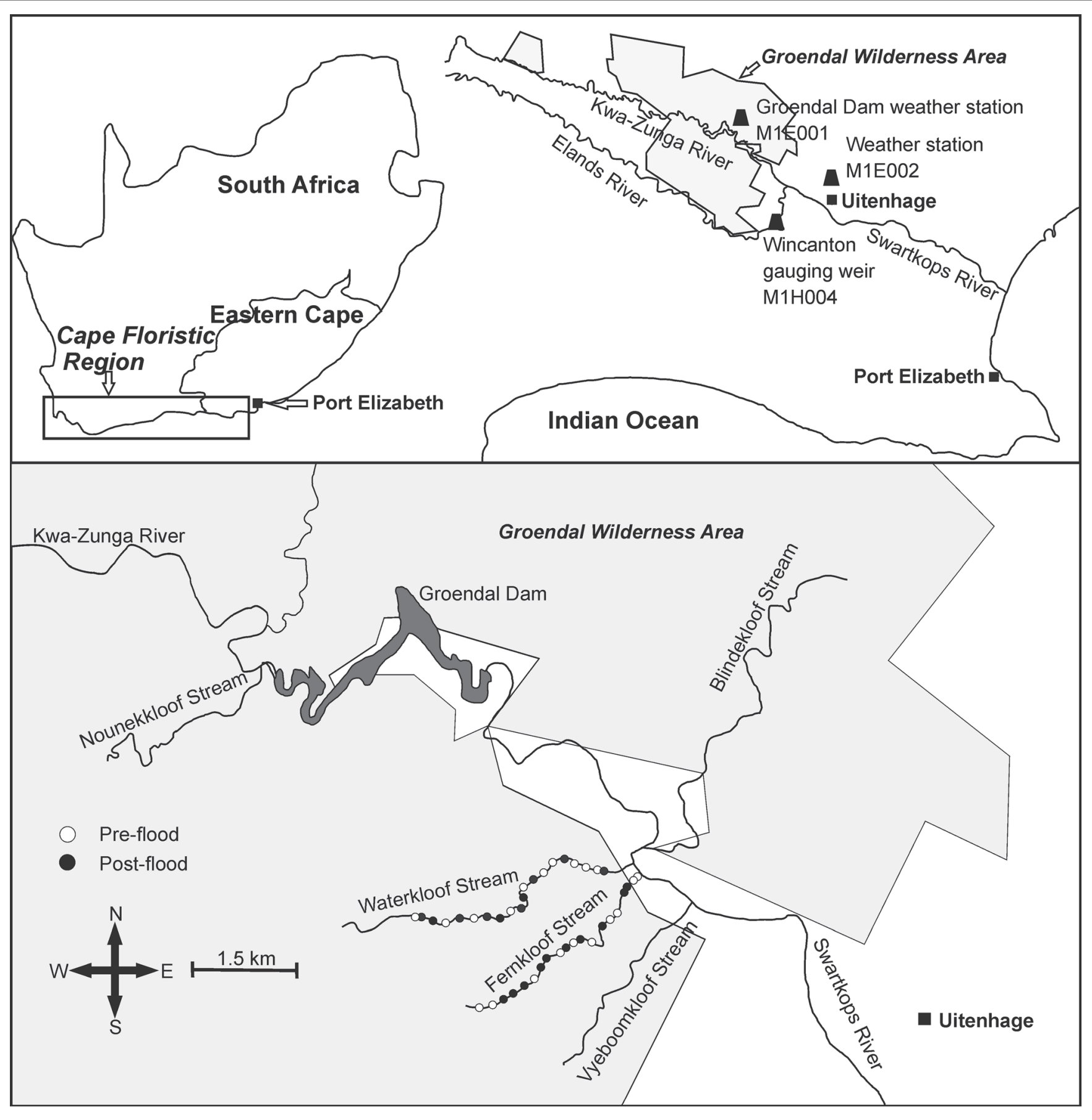

FIGURE 1: The situation and sites sampled on the Fernkloof and Waterkloof streams, headwater tributaries of the Swartkops River system within the Groendal Wilderness Area, Eastern Cape, South Africa. The position of the Wincanton gauging weir (M1H004) on the Elands River and the weather station (M1E001) at Groendal Dam are also noted.

Spearman rank order correlation was used to test for a relationship between rainfall and flow in the Swartkops River system headwater streams at a significance of $p<0.05$. The following criteria, outlined by Resh et al. (1988), were used to classify the magnitude of the flood disturbance as:

any relatively discrete event in time that is characterised by a frequency, intensity, and severity outside a predictable range, and that disrupts ecosystem, community, or population structure and changes resources or the physical environment. (p. 434)
These criteria were applied to peak flow data for the Swartkops River system to verify the magnitude of the flood in June 2012.

\section{Fish population dynamics}

Pre-flood and post-flood comparisons were limited to a single fish species, $P$. afer, as they were ubiquitously distributed from the limit of fish distributions ( $P$. afer distribution: Waterkloof $=3 \mathrm{~km}$; Fernkloof $=3 \mathrm{~km}$ ) in the upper reaches to the confluence with the mainstem KwaZunga River before the flood, allowing longitudinal 
analyses. To investigate the impact of a major flooding event on P. afer in headwater streams, pre-flood and postflood electrofishing catch per unit effort (CPUE, fish $\mathrm{m}^{-3}$ ) estimates were compared within the two streams using a main-effects analysis of variance (ANOVA) at a significance level of $p \leq 0.05$. Specifically, CPUE was tested for longitudinal trends (upper versus lower reaches), as well as flooding impact (pre-flood versus post-flood) and an interaction between the two factors.

Because of complications resulting from differences in sampling months, with the pre-flood survey occurring at the end of the spawning season and the post-flood survey at the beginning of the spawning season (Cambray 1994), $P$. afer juveniles $(<40 \mathrm{~mm})$ and adults $(>40 \mathrm{~mm})$ were analysed separately. To test the vulnerability of the two $P$. afer size classes to the flooding event, the frequency of occurrence (number of sites per stream reach where each size class was present expressed as a percentage of all sites in that reach) by stream reach (upper and lower reaches) was tested for significance by reach and pre-flooding and post-flooding using a chi-squared test of independence. All analyses were undertaken using MS Excel 2007, Microsoft ${ }^{\circledR}$ and Statistica 10.0, StatSoft ${ }^{\circledR}$.

\section{Results}

\section{Rainfall and flow}

Mean annual rainfall (mean \pm s.d.) for the period 16 February 1950 - 05 January 2012 was $620.7 \pm 212.3$ mm yr $^{-1}$. Rainfall was variable, falling in an unpredictable, erratic pattern (Figure 2). There was a highly significant correlation between rainfall (station M1E001 and M1E002) and peak flow (gauging weir M1H004) (Spearman $r=0.389 ; Z=9.45$; $p=0.000)$, highlighting the system's episodic nature. Peak flows between April 1965 and May 2012 were generally low (mean \pm s.d.: $30.3 \mathrm{~m}^{-3} \mathrm{~s}^{-1} \pm 202.3 \mathrm{~m}^{-3} \mathrm{~s}^{-1}$ ) and were predominantly $<25 \mathrm{~m}^{-3} \mathrm{~s}^{-1}(89 \%)$, with a further $8.7 \%$
$<500 \mathrm{~m}^{-3} \mathrm{~s}^{-1}$. During the 47 years on record, there were only four peak flows exceeding $1000 \mathrm{~m}^{-3} \mathrm{~s}^{-1}$ (Figure 2). The flooding event with peak flows of $1245 \mathrm{~m}^{-3} \mathrm{~s}^{-1}$ (a measure of instantaneous flow at peak discharge) in June 2012 was of a frequency, intensity and severity outside of the predictable range and resulted in changes to the physical environment, which, according to Resh et al. (1988), classified the flood as a major disturbance.

\section{Fish responses}

The distribution and abundance of fishes from the Fernkloof and Waterkloof streams pre-flood and post-flood are summarised in Table 1. Four species were recorded from the Fernkloof and Waterkloof streams, of which three were shared (native: P. afer and Cape kurper Sandelia capensis [Cuvier, 1831]; non-native: African sharptooth catfish Clarias gariepinus [Burchell, 1822]) and an additional non-native, banded tilapia Tilapia sparrmanii A. Smith 1840 was recorded in the Fernkloof stream only. Pseudobarbus afer distributions were limited to a $3 \mathrm{~km}$ stretch in both the Fernkloof and Waterkloof streams.

There were no significant pre-flood and post-flood longitudinal or interactive effects (stream reach: upper and lower reaches; disturbance: pre-flood and post-flood) in CPUE for P. afer in the Waterkloof stream (pre-flood mean \pm s.e.: $1.24 \pm 0.33$ fish $\mathrm{m}^{-3}$; post-flood mean \pm s.e.: $2.43 \pm$ 0.40 fish $\mathrm{m}^{-3}$ ) (Table 2). There was, however, a significant increase in post-flood $P$. afer CPUE in the Fernkloof stream (pre-flood mean \pm s.e.: $1.33 \pm 0.49$ fish $\mathrm{m}^{-3}$; post-flood mean \pm s.e.: $6.53 \pm 2.12$ fish $\mathrm{m}^{-3}$ ) (Figure 3; Table 2). The frequency of occurrence and length distributions for $P$. afer pre-flood and post-flood are summarised in Table 3 and Figure 4 .

The frequency of occurrence for juvenile $(<40 \mathrm{~mm})$ and adult $P$. afer was independent of stream reach and were subsequently grouped by stream (Table 3). The frequency

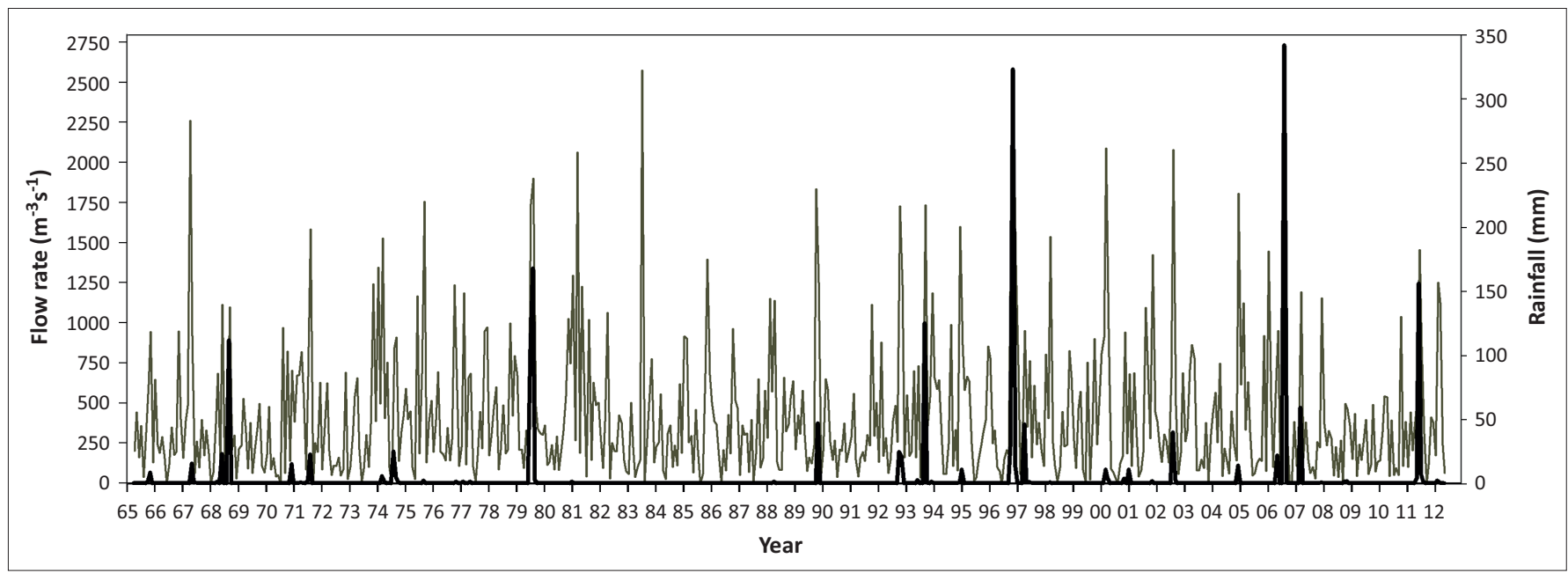

FIGURE 2: Monthly peak flows (black) at the Wincanton gauging weir on the Elands River and total monthly rainfall (grey) at Groendal Dam (16 February - 11 January 2006) and at Uitenhage (30 November 2006- 05 January 2012) illustrating rainfall and flow variability in the headwater tributaries of the Swartkops River system (flow data are missing for the period April 1981 - September 1986). 
TABLE 1: The stream zones (lower reaches, upper reaches), sites (10 sites), distribution, catch per unit effort (fish $\left.\mathrm{m}^{-3}\right)$, relative abundance (\%) of fishes by site (\%), including water-quality variables from site 1 in the lower reaches to site 10 in the upper reaches of the Fernkloof and Waterkloof streams, headwater tributaries of the Kwa-Zunga River within the Groendal Wilderness Area.

\begin{tabular}{|c|c|c|c|c|c|c|c|c|c|c|c|}
\hline \multirow[t]{2}{*}{ Sreams } & \multirow[t]{2}{*}{ Survey } & \multicolumn{5}{|c|}{ Lower reaches } & \multicolumn{5}{|c|}{ Upper reaches } \\
\hline & & 1 & 2 & 3 & 4 & 5 & 6 & 7 & 8 & 9 & 10 \\
\hline Fernkloof stream & - & - & - & - & - & - & - & - & - & - & - \\
\hline \multirow[t]{2}{*}{ Pseudobarbus afer } & Pre-flood & 0.00 & $0.03(33)$ & $0.38(73)$ & $1.22(91)$ & $2.15(80)$ & $1.20(75)$ & $0.99(71)$ & $4.36(100)$ & $3.23(100)$ & 0.00 \\
\hline & Post-flood & $0.10(10)$ & $0.36(68)$ & $4.62(86)$ & $7.67(88)$ & $11.11(88)$ & $4.40(96)$ & $9.87(100)$ & $4.60(100)$ & $27.89(100)$ & $11.25(100)$ \\
\hline \multirow[t]{2}{*}{ Sandelia capensis } & Pre-flood & $0.15(100)$ & $0.03(33)$ & $0.14(27)$ & $0.12(27)$ & $0.53(20)$ & $0.40(25)$ & $0.39(29)$ & 0.00 & 0.00 & 0.00 \\
\hline & Post-flood & $0.93(90)$ & $0.20(32)$ & $0.77(14)$ & $1.02(12)$ & $1.48(12)$ & 0.00 & 0.00 & 0.00 & 0.00 & 0.00 \\
\hline \multirow[t]{2}{*}{ Clarias gariepinus $\dagger$} & Pre-flood & 0.00 & $0.03(33)$ & 0.00 & 0.00 & 0.00 & 0.00 & 0.00 & 0.00 & 0.00 & 0.00 \\
\hline & Post-flood & 0.00 & 0.00 & 0.00 & 0.00 & 0.00 & 0.00 & 0.00 & 0.00 & 0.00 & 0.00 \\
\hline \multirow[t]{2}{*}{ Tilapia sparrmanii† } & Pre-flood & 0.00 & 0.00 & 0.00 & 0.00 & 0.00 & 0.00 & 0.00 & 0.00 & 0.00 & 0.00 \\
\hline & Post-flood & 0.00 & 0.00 & 0.00 & 0.00 & 0.00 & $0.17(4)$ & 0.00 & 0.00 & 0.00 & 0.00 \\
\hline \multirow[t]{2}{*}{ Temperature $\left({ }^{\circ} \mathrm{C}\right)$} & Pre-flood & 16.5 & 16.2 & 16.2 & 15.8 & 16.2 & 16.1 & 16.1 & 15.7 & 15.4 & 15.4 \\
\hline & Post-flood & 21 & 21.1 & 21.4 & 19.6 & 19.2 & 19.2 & 16.8 & 16.5 & 16.4 & 17.3 \\
\hline \multirow[t]{2}{*}{ Turbidity (NTU) } & Pre-flood & 0.5 & 0.43 & 0.28 & 0.29 & 0.35 & 0.21 & 0.37 & 0.43 & 0.2 & 0.18 \\
\hline & Post-flood & 0.17 & - & 0.15 & 0.19 & 0.41 & 0.34 & 0.32 & 0.17 & 0.28 & 0.22 \\
\hline \multirow[t]{2}{*}{ Conductivity $(\mu \mathrm{s} / \mathrm{cm})$} & Pre-flood & 302 & 303 & 301 & 301 & 301 & 296 & 304 & 291 & 275 & 260 \\
\hline & Post-flood & 230 & 221 & 222 & 222 & 220 & 218 & 214 & 219 & 215 & 213 \\
\hline Waterkloof stream & - & - & - & - & - & - & - & - & - & - & - \\
\hline \multirow[t]{2}{*}{ Pseudobarbus afer } & Pre-flood & $0.40(100)$ & $0.39(100)$ & $0.44(71)$ & $0.40(100)$ & $0.10(89)$ & $1.53(78)$ & $3.59(85)$ & $0.99(87)$ & $1.26(100)$ & $0.06(100)$ \\
\hline & Post-flood & $0.44(75)$ & $5.21(96)$ & $2.55(95)$ & $2.23(96)$ & $3.16(91)$ & $2.59(67)$ & $2.69(100)$ & $3.47(94)$ & $5.40(100)$ & $5.60(100)$ \\
\hline \multirow[t]{2}{*}{ Sandelia capensis } & Pre-flood & 0.00 & 0.00 & $0.18(29)$ & 0.00 & $0.12(11)$ & $0.44(22)$ & $0.63(15)$ & $0.15(13)$ & 0.00 & 0.00 \\
\hline & Post-flood & $0.15(25)$ & $0.21(4)$ & $0.12(5)$ & $0.09(4)$ & $0.30(9)$ & $1.29(33)$ & 0.00 & $0.22(6)$ & 0.00 & 0.00 \\
\hline \multirow[t]{2}{*}{ Clarias gariepinus $\dagger$} & Pre-flood & 0.00 & 0.00 & 0.00 & 0.00 & 0.00 & 0.00 & 0.00 & 0.00 & 0.00 & 0.00 \\
\hline & Post-flood & 0.00 & Saw 1 & 0.00 & 0.00 & 0.00 & 0.00 & 0.00 & 0.00 & 0.00 & 0.00 \\
\hline \multirow[t]{2}{*}{ Temperature $\left({ }^{\circ} \mathrm{C}\right)$} & Pre-flood & 17.4 & 17.6 & 17.6 & 17.9 & 18.2 & 15.2 & 15.5 & 13.7 & 14.3 & 14 \\
\hline & Post-flood & 15.9 & 16 & 16 & 15.7 & 15.7 & 16.1 & 15.9 & 16.5 & 16.8 & 17.3 \\
\hline \multirow[t]{2}{*}{ Turbidity (NTU) } & Pre-flood & 0.41 & 0.63 & 0.54 & 0.44 & 0.28 & 0.18 & 0.47 & 0.23 & 0.32 & 0.31 \\
\hline & Post-flood & 0.30 & 0.43 & 0.47 & 0.53 & 0.21 & 0.53 & 0.60 & 0.33 & 0.34 & 0.33 \\
\hline \multirow[t]{2}{*}{ Conductivity $(\mu \mathrm{s} / \mathrm{cm})$} & Pre-flood & 267 & 263 & 257 & 259 & 250 & 256 & 250 & 245 & 254 & 234 \\
\hline & Post-flood & 212 & 214 & 209 & 209 & 209 & 207 & 206 & 200 & 202 & 216 \\
\hline
\end{tabular}

NTU, nephelometric turbidity units.

$\dagger$, non-native species.

TABLE 2: A summary of pre-flood and post-flood longitudinal (upper and lower stream reaches) and disturbance (pre-flood and post-flood) main-effects ANOVA results for Pseudobarbus afer CPUE (fish $\mathrm{m}^{-3}$ ) from the Waterkloof and Fernkloof streams, headwater tributaries of the Kwa-Zunga River within the Groendal Wilderness Area.

\begin{tabular}{lcccc}
\hline Streams & DF & MS & $\boldsymbol{F}$-statistic & $p$-value \\
\hline Fernkloof stream & - & - & - & - \\
Site & 9 & 28.1854 & 1.45811 & 0.291616 \\
Pre/Post & 1 & 135.4398 & 7.00667 & 0.026606 \\
Site*Pre/Post & - & - & - & - \\
Error & 9 & 19.3301 & - & - \\
Waterkloof stream & - & - & - & - \\
Site & 9 & 1.15082 & 0.71742 & 0.685614 \\
Pre/Post & 1 & 7.03571 & 4.38604 & 0.065725 \\
Site*Pre/Post & - & - & - & - \\
Error & 9 & 1.60412 & - & - \\
\hline CPUE, catch per unit effort; DF, degrees of freedom; MS, mean square &
\end{tabular}

CPUE, catch per unit effort; DF, degrees of freedom; MS, mean square.

of occurrence of juvenile and adult $P$. afer was independent of flooding for the Waterkloof (pre-flood versus postflood: $\left.\chi^{2}=0.027, d f=1, p=0.87\right)$ and Fernkloof streams (pre-flood versus post-flood: $\chi^{2}=0.044, d f=1, p=0.83$ ) (Table 3).

In the Waterkloof stream, $P$. afer size distributions were similar between stream reaches and pre-flooding and post-flooding (pre-flood lower mean, range: 43.7, $22 \mathrm{~mm}$ $74 \mathrm{~mm}$ fork length (FL); pre-flood upper mean, range: 40.7,

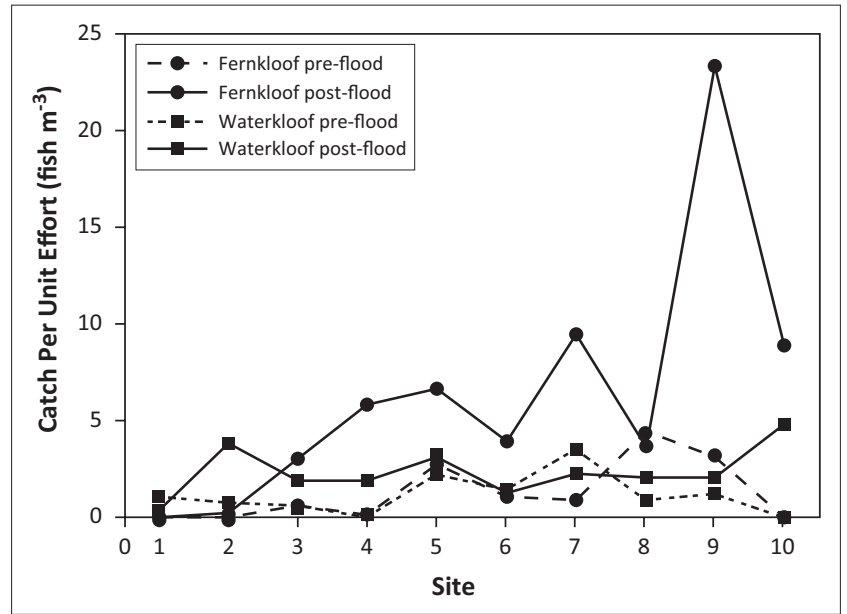

FIGURE 3: Pre-flood and post-flood longitudinal abundance trends for Pseudobarbus afer catch per unit effort (fish $\mathrm{m}^{-3}$ ) from the Waterkloof and Fernkloof streams, headwater tributaries of the Kwa-Zunga River within the Groendal Wilderness Area, Eastern Cape, South Africa.

$16 \mathrm{~mm}$ - $71 \mathrm{~mm}$ FL; post-flood lower mean, range: 42.8, $21 \mathrm{~mm}-67 \mathrm{~mm}$ FL; post-flood upper mean, range: 47.2, $28 \mathrm{~mm}-81 \mathrm{~mm}$ FL) (Figure 4). In the Fernkloof stream, the mean length of $P$. afer was larger in the lower reaches but similar before and after the flood (pre-flood lower mean, range: 53.0, $11 \mathrm{~mm}-96 \mathrm{~mm}$ FL; pre-flood upper mean, range: 43.0, 24 mm - 72 mm FL; post-flood lower mean, range: 52.0, 
$30 \mathrm{~mm}-87 \mathrm{~mm}$ FL; post-flood upper mean, range: 46.3, $21 \mathrm{~mm}-100 \mathrm{~mm}$ FL).

TABLE 3: The frequency of occurrence ( $\%$ of sites containing Pseudobarbus afer) of juvenile $(<40 \mathrm{~mm})$ and adult $(>40 \mathrm{~mm})$ Pseudobarbus afer pre-flood and post-flood separated by stream reach (lower and upper) for the Fernkloof and Waterkloof streams headwater tributaries of the Kwa-Zunga River within the Groendal Wilderness Area.

\begin{tabular}{|c|c|c|c|}
\hline Streams & $\begin{array}{c}\text { Juvenile } \\
(<40 \mathrm{~mm})(\%)\end{array}$ & $\begin{array}{c}\text { Adult }(>40 \mathrm{~mm}) \\
(\%)\end{array}$ & $\begin{array}{l}\text { Mean length } \\
\text { (range) } \mathrm{mm} \text { FL }\end{array}$ \\
\hline $\begin{array}{l}\text { Waterkloof stream } \\
\text { pre-flood }\end{array}$ & - & - & - \\
\hline Lower reaches & 100 & 100 & $43.7(22-74)$ \\
\hline Upper reaches & 100 & 100 & $40.7(16-71)$ \\
\hline $\begin{array}{l}\text { Waterkloof stream } \\
\text { post-flood }\end{array}$ & - & - & - \\
\hline Lower reaches & 100 & 100 & $42.8(21-67)$ \\
\hline Upper reaches & 80 & 100 & $47.2(28-81)$ \\
\hline $\begin{array}{l}\text { Fernkloof stream } \\
\text { pre-flood }\end{array}$ & - & - & - \\
\hline Lower reaches & 40 & 60 & $53.0(11-96)$ \\
\hline Upper reaches & 80 & 80 & $43.0(24-72)$ \\
\hline $\begin{array}{l}\text { Fernkloof stream } \\
\text { post-flood }\end{array}$ & - & - & - \\
\hline Lower reaches & 80 & 80 & $52.0(30-87)$ \\
\hline Upper reaches & 100 & 100 & $46.3(21-100)$ \\
\hline
\end{tabular}

$\mathrm{FL}$, fork length.

\section{Discussion}

Flood-related disturbances typically elicit a variety of responses from fishes in stream environments, the nature of which are related to the predictability, magnitude/intensity and duration of the event (Lytle \& Poff 2004) as well as the specific adaptations of the fishes to the abiotic conditions of that environment (Franssen et al. 2006; Lytle \& Poff 2004). In the Fernkloof and Waterkloof streams, P. afer demonstrated resilience to a major flooding event.

In both small streams, there were no longitudinal trends in $P$. afer abundance before or after the flood, but overall abundance post-flooding in the Fernkloof stream was higher. This may have been the result of the inability to sample the exact sites before and after the flood as some pools were filled up by flood deposition. The nearest pool to the pre-flood site was sampled, which may have resulted in sampling a refuge pool where post-flood abundances were high as a result of collection of fishes from that stream segment. Good recruitment during the 2010/2011 spawning season might also have led to the observed increase in abundance as during this period rainfall was higher than
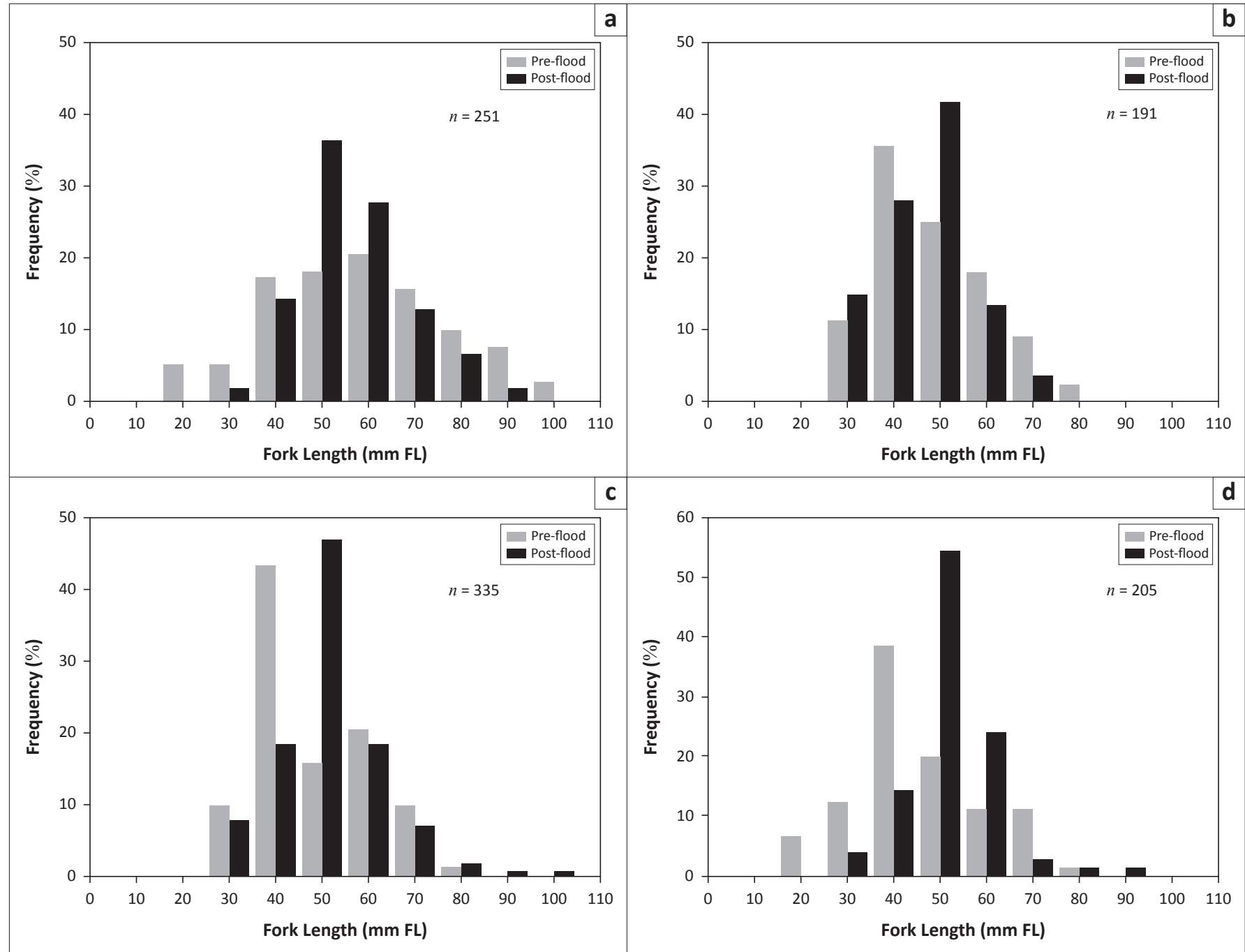

FIGURE 4: Pre-flood and post-flood length frequency distribution for Pseudobarbus afer from the upper and lower reaches of the Fernkloof ( $\mathrm{a}=$ lower; $\mathrm{c}=\mathrm{upper}$ ) and Waterkloof ( $b=$ lower; $c=$ upper) streams, headwater tributaries of the Kwa-Zunga River within the Groendal Wilderness Area, Eastern Cape, South Africa. 
the preceding two spawning seasons. Increased recruitment during periods of good flow was recorded by Franssen et al. (2006) for intermittent prairie stream fishes in northeastern Kansas, USA. However, the P. afer length frequency data from the Waterkloof and Fernkloof streams do not support this, as size structuring before and after the flood was similar.

The vulnerability of stream fishes to flood disturbance is not always clearly evident from overall abundance trends, but in some cases certain life history stages of particular species may be more vulnerable to disturbance than others (Gasith \& Resh 1999; Letcher \& Terrick 1998; Lytle \& Poff 2004). In New England streams in the USA, a massive localised flood caused an age-0 year-class failure in brook trout Salvelinus fontinalis (Mitchill, 1815) and brown trout Salmo trutta Linnaeus 1758 and a large decrease in abundance of Atlantic salmon Salmo salar Linnaeus 1758 (Letcher \& Terrick 1998). Similar results have been recorded for other species after catastrophic flood events (Dolloff et al. 1994; Harvey 1987; Matthews 1986; Nislow et al. 2002).

This was not the case for $P$. afer as there were no significant changes in the occurrence of either juvenile or adult $P$. afer following the flood. Both life history stages were distributed throughout both streams from their confluence with the mainstream Kwa-Zunga in the lower reaches, to the limit of $P$. afer distribution in the upper reaches. The susceptibility of juvenile fishes to flood displacement and mortality has been documented to decrease rapidly with a small increase in length (Harvey 1987) and P. afer may show similar trends in changing vulnerability with size. In the nearby Wit River, a headwater tributary of the Gamtoos River system, Cambray (1994) reported that late free embryos and early larvae drift out of the areas where they were spawned. During the current study, the flooding event took place 3-5 months after the peak spawning season of $P$. afer (Cambray 1994), perhaps allowing young-of-the-year fish time to grow out of the most vulnerable life history stages.

Distribution and movement of non-native species indicated species-specific and stream-specific flood response. For example, after the same flood, Ellender, Woodford and Weyl (2015) noted that the flood event appeared to have flushed C. gariepinus out of the Fernkloof stream but facilitated its penetration into the Waterkloof stream. Temporal longitudinal movement was also noted in the Blindekloof stream, another Kwa-Zunga River tributary, during a period of prolonged flow ( \pm 5 months) following the June 2012 flood, when C. gariepinus penetrated $5 \mathrm{~km}$ upstream from the mainstem (Ellender et al. 2015).

In conclusion, the observed resilience of $P$. afer populations to a major flooding event is most likely related to their evolution in river systems characterised by environmental stochasticity (Dolloff et al. 1994; Magalhaes et al. 2003; Pires et al. 2008). The long-term persistence of $P$. afer in relatively pristine isolated headwater refugia may therefore not be threatened by flood disturbances of the observed magnitude and intensity. The biggest long-term threat may be the floodfacilitated penetration of headwater refugia by non-native species.

\section{Acknowledgements}

B.R.E. received financial support from: the South AfricaNetherlands Research Programme on Alternatives in Development (SANPAD project 10/06), the National Research Foundation of South Africa (NRF), Rhodes University, the DST/NRF Centre of Excellence for Invasion Biology and the Water Research Commission (WRC Project No. K5/1957/4, K5/2039 and K5/2261). Eastern Cape Parks Board and staff of the Groendal Wilderness Area are thanked for access and for their logistical assistance. Geraldine Taylor and Patrick Gourley are thanked for field assistance. Research was conducted following SAIAB animal ethics guidelines. Research permits were issues by the Eastern Cape Department of Economic Development and Environmental Affairs (DEDEA) and Eastern Cape Parks.

\section{Competing interests}

The authors declare that they have no financial or personal relationships which may have inappropriately influenced them in writing this article.

\section{Authors' contributions}

B.R.E. (South African Institute for Aquatic Biodiversity) was responsible for study conceptualisation, data collection, analyses, writing and editing the manuscript. O.L.F.W. (South African Institute for Aquatic Biodiversity) contributed to conceptualising the study, writing and editing the manuscript.

\section{References}

Acocks, J.P.H., 1975, 'Veld types of South Africa', Memoirs of the Botanical Survey of South Africa 40, 1-128.

Cambray, J.A., 1994, 'The comparative reproductive styles of two closely related African minnows (Pseudobarbus afer and $P$. asper) inhabiting two different sections of the Gamtoos River system', Environmental Biology of Fishes 41, 247-268. http://dx.doi.org/10.1007/BF02197848

Campbell, B.M., 1985, 'A classification of the mountain vegetation of the fynbos biome', Memoirs of the Botanical Survey of South Africa 50, 1-21.

Dolloff, C.A., Flebbe, P.A. \& Owen, M.D., 1994, 'Fish habitat and fish populations in a southern Appalachian watershed before and after Hurricane Hugo', Transactions of the American Fisheries Society 123, 668-678. http://dx.doi.org/10.1577/15488659(1994)123<0668:FHAFPI>2.3.CO;2

DWAF, 2012, Department of Water Affairs and Forestry River station database, viewed 28 June 2012, from http://www.dwaf.gov.za/hydrology/

Ellender, B.R., 2013, 'Ecological consequences of non-native fish invasions in Eastern Cape headwater streams', PhD thesis, Department of Ichthyology \& Fisheries Science, Rhodes University.

Ellender, B.R., Weyl, O.L.F. \& Swartz, E.R., 2011, 'Invasion of a headwater stream by non-native fishes in the Swartkops River system, South Africa', African Zoology 46, 39-46. http://dx.doi.org/10.3377/004.046.0116

Ellender, B.R., Woodford, D.J. \& Weyl, O.L.F., 2015, 'The invasibility of small headwater streams by an emerging invader, Clarias gariepinus', Biological Invasions 17 57-61. http://dx.doi.org/10.1007/s10530-014-0744-8

Fausch, K.D., Rieman, B.E., Dunham, J.B., Young, M.K. \& Peterson, D.P., 2009, 'Invasion versus isolation: Trade-offs in managing native salmonids with barriers to upstream movement', Conservation Biology 23, 859-870. http://dx.doi.org/10.1111/j.1365 2427.2006.01640.x

Franssen, N.R., Gido, K.B., Guy, C.S., Tripe, J.A., Shrank, S.J. \& Strakosh, T.R. et al., 2006, 'Effects of floods on fish assemblages in an intermittent prairie stream', Freshwater Biology, 51, 2072-2086. http://dx.doi.org/10.1111/j.1365-2427.2006.01640.x 
Gasith, A. \& Resh, V.H., 1999, 'Streams in Mediterranean climate regions: Abiotic influences and biotic responses to predictable seasonal events', Annual Review of Ecology and Systematics 30, 51-81. http://www.jstor.org/stable/221679. http:// Ecology and Systematics 30, 51-81. http:///Ww
dx.doi.org/10.1146/annurev.ecolsys.30.1.51

Harvey, B.C., 1987, 'Susceptibility of young-of-the-year fishes to downstream displacement by flooding', Transactions of the American Fisheries Society 116 851-855. http://dx.doi.org/10.1577/1548-8659(1987)116<851:SOYFTD>2.0.CO;2

Labbe, T.R. \& Fausch, K.D., 2000, 'Dynamics of intermittent stream habitat regulate persistence of a threatened fish at multiple scales', Ecological Applications 10 1774-1791. http://dx.doi.org/10.1890/1051-0761(2000)010[1774:DOISHR]2.0. $\mathrm{CO} ; 2$

Letcher, B.H. \& Terrick, T.D., 1998, 'Maturation of male age-0 Atlantic salmon following a massive, localized flood', Journal of Fish Biology 53, 1243-1252. http://dx.dol. org/10.1111/j.1095-8649.1998.tb00245.x

Lytle, D.A. \& Poff, N.L., 2004, 'Adaptation to natural flow regimes', Trends in Ecology \& Evolution 19, 94-100. http://dx.doi.org/10.1016/j.tree.2003.10.002

Magalhaes, M.F., Schlosser, I.J. \& Collares-Pereira, M.J., 2003, 'The role of life history in the relationship between population dynamics and environmental variability in two Mediterranean stream fishes', Journal of Fish Biology 63, 300-317. http:// dx.doi.org/10.1046/j.1095-8649.2003.00148.x

Marr, S.M., Marchetti, M.P., Olden, J.D., García-Berthou, E., Morgan, D.L., Arismendi, I. et al., 2010, 'Freshwater fish introductions in Mediterranean-climate regions: Are there commonalities in the conservation problem?', Diversity and Distributions, 16, 606-619. http://dx.doi.org/10.1111/j.1472-4642.2010.00669.x

Matthews, W.J., 1986, 'Fish faunal structure in an Ozark stream: Stability, persistence and a catastrophic flood', Copeia 2, 388-397. http://www.jstor.org/ stable/1444997

Medeiros, E.S.F. \& Maltchik, L., 2001, 'Fish assemblage stability in an intermittently flowing stream from the Brazilian semiarid region', Austral Ecology 26, 156-164. http://dx.doi.org/10.1046/j.1442-9993.2001.01099.x

Meyer, J.L., Strayer, D.L., Wallace, J.B., Eggert, S.L., Helfman, G.S. \& Leonard, N.E. 2007, 'The contribution of headwater streams to biodiversity in river networks', Journal of the American Water Resources Association 43, 86-103. http://dx.doi. org/10.1111/j.1752-1688.2007.00008.x
Nislow, K.H., Magilligan, F.J., Folt, C.L. \& Kennedy, B.P., 2002, 'Within-basin variation in the short-term effects of a major flood on stream fishes and invertebrates', Journal of Freshwater Ecology 17, 305-318. http://dx.doi.org/10.1080/0270506 0.2002 .9663899

Pires, A.M., Magalhães, M.F., Moreira Da Costa, L., Alves, M.J. \& Coelho, M.M., 2008, 'Effects of an extreme flash flood on the native fish assemblages across a Mediterranean catchment', Fisheries Management and Ecology 15, 49-58. http:// dx.doi.org/10.1111/j.1365-2400.2007.00570.x

Resh, V.H., Brown, A. V, Covich, A.P., Gurtz, M.E., Li H.W., Minshall, G.W. et al., 1988, 'The role of disturbance in stream ecology', Journal of the North American Benthological Society 7, 433-455. http://www.jstor.org/stable/1467300

Russell, I.A., 2011, 'Conservation status and distribution of freshwater fishes in South African national parks', African Zoology 46, 117-132. http://dx.doi. org/10.3377/004.046.0103

Schlosser, I.J. \& Angermeier, P.L., 1995, 'Spatial variation in demographic processes of lotic fishes: Conceptual models, empirical evidence, and implications for conservation', American Fisheries Society Symposium 17, 392-401.

Swartz, E. \& Impson, D., 2007, 'Pseudobarbus afer', in IUCN Red List of Threatened Species, version 2014.2, viewed 13 October 2014, from http://www.iucnredlist. org

Swartz, E.R., Skelton, P.H. \& Bloomer, P., 2007, 'Sea-level changes, river capture and the evolution of populations of the Eastern Cape and fiery redfins (Pseudobarbus
afer and Pseudobarbus phlegethon, Cyprinidae) across multiple river systems in afer and Pseudobarbus phlegethon, Cyprinidae) across multiple river systems in
South Africa', Journal of Biogeography 2086-2099. http://dx.doi.org/10.1111/ South Africa', Journal of

Tweddle, D., Bills, R., Swartz, E., Coetzer, W., Da Costa, L., Engelbrecht, J. et al., 2009 , 'The status and distribution of freshwater fishes', in W.R.T. Darwall, K.G. Smith, D. Tweddle \& P. Skelton, (eds.), The status and distribution of freshwater biodiversity in Southern Africa, pp. 21-37, International Union for Conservation of Nature, Gland, Switzerland, and South African Institute for Aquatic Biodiversity, Nature, Gland, Switzerland,
Grahamstown, South Africa.

Weyl, O.L.F., Finlayson, B., Impson, N.D., Woodford, D.J. \& Steinkjer, J., 2014 'Threatened endemic fishes in South Africa's Cape Floristic Region: A new 'Threatened endemic fishes in South Africa's Cape Floristic Region: A new 080/03632415.2014.914924 